\title{
CAN SCLERODERMA BE INDUCED BY ANESTHETICS? CASE REPORT
}

\author{
CZY ŚRODKI ZNIECZULAJACE MOGA WYWOŁAĆ SKLERODERMIĘ? \\ OPIS PRZYPADKU
}

Università Cattolica del Sacro Cuore, Rome, Italy

Department of Public Health

\begin{abstract}
Occupational exposure to solvents is consistently associated with the risk of systemic sclerosis. We pose the question of whether the occupational exposure to anesthetics may favor the occurrence of this disease. This paper describes an incidence of systemic sclerosis in the case of an anesthesiologist who had been occupationally exposed to high doses of anesthetic in the operating room. Anecdotal cases in the literature give limited support to the causal association of the occupational exposure to anesthetics and systemic sclerosis. The extremely limited number of workers exposed makes it necessary to report all cases observed in order to assess the degree of the occupational risk for anesthesiologists. Med Pr 2016;67(4):557-560
\end{abstract}

Key words: cancer, occupational exposure, operating room, anesthetics, solvent, solvent exposure

\begin{abstract}
STRESZCZENiE
Narażenie zawodowe na rozpuszczalniki jest związane z ryzykiem wystąpienia sklerodermii. Celem pracy było zbadanie, czy narażenie zawodowe na środki znieczulające również może wywołać tę chorobę. W artykule przedstawiono przypadek sklerodermii u lekarki anestezjologa, która była narażona na wysokie dawki środków znieczulających na sali operacyjnej. Opublikowane dotąd opisy przypadków nie pozwalają jednoznacznie powiązać narażenia zawodowego na środki znieczulające z wystąpieniem sklerodermii. Ze względu na niewielką liczbę pracowników narażonych na te środki powinny być raportowane wszystkie przypadki wystąpienia sklerodermii w celu określenia stopnia ryzyka zawodowego u anestezjologów. Med. Pr. 2016;67(4):557-560
\end{abstract}

Słowa kluczowe: rak, narażenie zawodowe, sala operacyjna, środki znieczulające, rozpuszczalnik, narażenie na rozpuszczalniki

Corresponding author / Autorka do korespondencji: Nicola Magnavita, Università Cattolica del Sacro Cuore,

Department of Public Health, Largo Gemelli 8, 00168 Rome, Italy, e-mail: nicolamagnavita@gmail.com

Received: June 11, 2015, accepted: February 23, 2016

\section{INTRODUCTION}

Systemic sclerosis or scleroderma (SS) is a rare multisystem disease characteristic of the incidence ranging between $2-12$ cases per year per million people at risk. The two main types, limited (morphea) or diffuse SS, have a different evolution and prognosis. In the recent decades there has been an increase in the incidence of the disease, that has now reached approx. 20 cases per million, mainly on account of improvements in diagnostic criteria. The disease is characterized by an alteration in microcirculation that leads to massive deposition of collagen in the connective tissue of various parts of the body, including the skin, esophagus, lungs, gastro-intestinal tract, the kidneys, heart and some internal organs [1].

The etiology of scleroderma is not clear. Epidemiological data suggests a complex interaction of genetic, environmental and hormonal alterations that give rise to fibrotic changes. Among occupational factors, sufficient evidence has been collected to establish the association between the occupational exposure to silica and scleroderma: a meta-analysis has reported that the risk of the SS has at least tripled among workers exposed to silica [2]. Vinyl chloride monomer is another known factor in the case of the morphea and the SS [3-5]. More recently, the occupational exposure to vinyl acetate has also been associated with the onset of the SS and connective tissue disorders [6].

To date, the question that has aroused most concern due to the possible association with scleroderma is the occupational exposure to solvents. The term solvent includes a large number of chemicals that are not related to one another. For practical and preventive purposes, it is important to understand which categories of sol- 
vents may be associated with scleroderma. A recent review concludes that the high cumulative exposure to aromatic solvents, chlorinated solvents, trichlorethylene, ketones and white spirit has an impact upon the development of the SS, and the association between the SS and the occupational exposure may be variable according to gender [7]. A prospective study has recently shown that occupational cases have the worst prognosis as compared to idiopathic ones. The exposure to crystalline silica/solvents is correlated with more severe forms of the SS characterized by diffuse cutaneous involvement, interstitial lung disease, general microangiopathy (digital ulcers and myocardial dysfunction), and association with cancer [8].

Anesthetics consist of a heterogeneous group of substances, all of which have a solvent effect. Our study poses the question of whether the occupational exposure to anesthetics may induce the occurrence of systemic sclerosis.

\section{CASE REPORT}

A 59-year-old woman was referred to our outpatient occupational medicine unit to determine the cause of her diseases. She was a physician specializing in anesthesia and intensive care, and had been working in the operating theatre of a public hospital since 1980. She reported that until 1989 the hospital had been located in a former convent where halothane and other halogenated ethers had been extensively used in the operating theaters. The latter had not been equipped with devices for the removal of anesthetics, so the surgical staff members had been exposed to very high levels of anesthetic exposure until at least the mid-90's. Subsequently the environmental situation gradually improved when the hospital was transferred to a new building and the use of chloro-fluoro-halogenated anesthetics was gradually reduced. The subject also reported the occupational exposure to night work, physical agents (ionizing radiation), and biological agents.

In July 2005, she reported the appearance of swelling of the right hand, in result of which she underwent surgery. The subsequent onset of paresthesia, edema, swelling and Raynaud's phenomenon in her feet and left hand suggested the need for rheumatologic tests which documented the presence of anti-nuclear antibody (ANA) and lupus anti-coagulant (LAC) antibody. A biopsy revealed systemic sclerosis. Chest X-rays showed basal bronchiectasis. She was treated with prednisone and cyclophosphamide, and subsequent- ly with monoclonal antibodies (rituximab (RTX), a monoclonal antibody (mAb) against B-lymphocyte antigen (CD20)), causing improvement in the skin and lung changes. This treatment was followed by the onset of diabetes mellitus type II. Since 2009 she had been undergoing treatment with felodipine, acetylsalicylic acid, and trometamol. She complained of dysphagia, alternating bowel function, gait difficulties for forefoot numbness, and shortness of breath on exertion. There is no history of digital ulcers.

In July 2008, after a highly undifferentiated tumor of the left axillary lymph nodes with occult primary had been detected, the subject underwent depletion of the armpit, chemotherapy and subsequent radiotherapy (the last cycle in February 2009). During radiation treatment, the patient reported an episode of pleuropericarditis. She had also had episodes of paroxysmal tachycardia since 2006. In October 2012 some improvement was obtained by performing ablation.

During a physical examination in December 2014, we observed prominence of perioral wrinkles, without ongoing digital ulcer disease.

The patient gave an informed consent to the publication of this paper.

\section{DISCUSSION}

The onset of scleroderma has been associated with the administration of a large number of drugs including: pentazocine [9], cocaine [10], mepivacaine [11], bleomycin and d-penicillamine [12], doxorubicin and cyclophosphamide [13]. Some of those drugs are commonly used in anesthesiology. The occurrence of a family cluster of dermatomyositis and scleroderma has been associated with the use of dental anesthetics [14]. These studies have a limited interest in our case because anesthesiologists are not occupationally exposed to drugs that are administered intravenously or intramuscularly. They are, however, occupationally exposed to anesthetics administered via inhalation.

Until recently high levels of anesthetic pollution in the operating rooms of Italian hospitals have been often reported. A review of studies conducted in the late 1980's showed that pollution during surgery exceeded $1000 \mathrm{ppm}$ of nitrous oxide (against a time weighted average threshold limit value (TLV-TWA) of $50 \mathrm{ppm}$ established in 1989), while mixed halogenated ethers (halothane, enflurane, isoflurane) often showed levels greater than $100 \mathrm{ppm}$, as compared with a TLV-TWA of $50 \mathrm{ppm}$ [15]. Appreciable concentrations of local an- 
esthetics were also present in adjacent operating rooms and side rooms where operating staff members could rest. On account of this situation, the Italian Ministry of Health decided to issue a circular requiring the adoption of standards and controls to evaluate exposure levels and limit the duration of occupational exposure [16]. Over the years, the gradual introduction of devices for collecting vapors and the substitution of ethers with less toxic products have led to mitigation of that risk.

Halogenated anesthetics share many physicalchemical and toxicological properties with solvents. Epidemiological evidence has shown solvents to be responsible for the development of scleroderma. Evaluation of causal links is particularly difficult in the case of scleroderma. The rarity of the disease restricts application of the classical criteria of Bradford-Hill [17], and the limited number of workers exposed to anesthetics (about 10000 anesthesiologists in Italy) hinders epidemiological investigation. On account of similarities in their respective structural formulas and toxicological properties, bromo-fluoro-chlorinated anesthetics may behave in a way similar to the halogenated aliphatic hydrocarbons that are known to cause scleroderma.

In the case we observed, the subject had been exposed to high doses of anesthetics, especially at the beginning of her working career. In this specific case, however, the dose was not of particular importance. We must remember that the possible triggering of autoimmune mechanisms does not necessarily require a specific threshold, nor is it necessary for the exposure to be maintained in order to observe disease progression. The time interval between the exposure and the onset of clinical signs may be considered reasonably compatible with an occupational etiology. Finally, there is biological plausibility, even if this is limited by the lack of the current knowledge on scleroderma.

The solvents and their reactive metabolites bind covalently to proteins, thus stimulating an autoimmune reaction [18]. This general mechanism applies to all chemical compounds associated with scleroderma. The toxic substances implicated in scleroderma specifically induce a redistribution of nuclear autoantigens, thus favoring the presentation of sub-nuclear particles to cytoplasmic proteasomes. In other words, the nuclear autoantibodies of scleroderma require the intervention of a toxic substance to be processed by the ubiquitin proteasome system [19]. Recent studies indicate that the cells of the innate immune system, pattern recognition receptors, and activation of dendritic cells by chemicals play a prominent role in scleroderma [20].
On the basis of the current knowledge on plausible causation, we believe that the occupational exposure to anesthetics may have caused scleroderma. We have drawn attention to the aforementioned case in order to encourage the reporting of other similar cases.

An important issue of this case is related to the appearance of a neoplasm three years after the onset of scleroderma. Cancer and autoimmune diseases are often associated with scleroderma, and it is difficult to determine which is the primary disease. Malignant neoplasms may induce a wide variety of paraneoplastic rheumatological syndromes [21,22]. The opposite is also true, as it has been observed that scleroderma caused by the occupational exposure to solvents may frequently result in cancer [8]. Recent studies have suggested a model of paraneoplastic autoimmunity in which cross-reactive immune responses may target autoantigens expressed both in cancers and diseased autoimmune target tissues [23]. A retrospective study of a British cohort of the SS cases has indicated that $7.1 \%$ of patients had a history of cancer shortly after the onset of the SS, with breast cancer being the commonest neoplasm [24]. In this case the long latency period required for the onset of cancer reduces the likelihood of a paraneoplastic syndrome and supports the hypothesis that both the SS and subsequent cancer have been related to the occupational exposure to anesthetics.

\section{CONCLUSIONS}

This report highlights the importance of a comprehensive and detailed collection of occupational exposures for patients diagnosed with systemic sclerosis. Only the observation of a large number of people exposed to solvents may help us understand if there is an association between the occupational exposure to anesthetics and the SS.

\section{REFERENCES}

1. Nikpour M, Stevens WM, Herrick AL, Proudman SM. Epidemiology of systemic sclerosis. Best Pract Res Clin Rheumatol. 2010;24(6):857-69, http://dx.doi.org/10.1016/ j.berh.2010.10.007.

2. McCormic ZD, Khuder SS, Aryal BK, Ames AL, Khuder SA. Occupational silica exposure as a risk factor for scleroderma: A meta-analysis. Int Arch Occup Environ Health. 2010;83(7):763-9, http://dx.doi.org/10.1007/ s00420-009-0505-7.

3. Falappa P, Magnavita N, Bergamaschi A, Colavita N. Angiographic study of digital arteries in workers exposed 
to vinyl chloride. Br J Ind Med. 1982;39:169-72, http:// dx.doi.org/10.1136/oem.39.2.169.

4. Magnavita N, Bergamaschi A, Garcovich A, Giuliano G. Vasculitic purpura in vinyl chloride disease: A case report. Angiology. 1986;37(5):382-8, http://dx.doi.org/10. 1177/000331978603700508.

5. Czernielewski A, Kieć-Świerczyńska M, Głuszcz M, Woźniak L. Dermatological aspects of so called vinyl chloride monomer disease. Derm Beruf Umwelt. 1979;27:108-12.

6. Magnavita N. Scleroderma cluster among type-setters. G Ital Med Lav Ergon. 2007;29(3 Suppl):440-1.

7. Marie I, Gehanno JF, Bubenheim M, Duval-Modeste AB, Joly P, Dominique S, et al. Prospective study to evaluate the association between systemic sclerosis and occupational exposure and review of the literature. Autoimmun Rev. 2014;13(2):151-6, http://dx.doi.org/10.1016/j.autrev. 2013.10.002.

8. Marie I, Menard JF, Duval-Modeste AB, Joly P, Dominique $\mathrm{S}$, Bravard $\mathrm{P}$, et al. Association of occupational exposure with features of systemic sclerosis. J Am Acad Dermatol. 2015;72(3):456-64, http://dx.doi.org/10.1016/ j.jaad.2014.11.027.

9. Bellman B, Berman B. Localized indurated brown plaques on arms and right buttock. Pentazocine-induced morphea. Arch Dermatol. 1996;132(11):1366-9.

10. Attoussi S, Faulkner ML, Oso A, Umoru B. Cocaineinduced scleroderma and scleroderma renal crisis. South Med J. 1998;91(10):961-3, http://dx.doi.org/10.10 97/00007611-199810000-00013.

11. Ueda T, Niiyama S, Amoh Y, Katsuoka K. Linear scleroderma after contusion and injection of mepivacaine hydrochloride. Dermatol Online J. 2010;16(5):11.

12. D'Cruz D. Autoimmune disease associated with drugs, chemicals and environmental factors. Toxicol Lett. 2000;112-3:421-32, http://dx.doi.org/10.1016/S0378-4274 (99)00220-9.

13. Alexandrescu DT, Bhagwati NS, Wiernik PH. Chemotherapy-induced scleroderma: A pleiomorphic syndrome. Clin Exp Dermatol. 2005;30(2):141-5, http:// dx.doi.org/10.1111/j.1365-2230.2004.01668.x.

14. Rose T, Nothjunge J, Schlote W. Familial occurrence of dermatomyositis and progressive scleroderma after in- jection of a local anaesthetic for dental treatment. Eur J Pediatr. 1985;143(3):225-8, http://dx.doi.org/10.1007/ BF00442147.

15. Magnavita N, de Lorenzo G, Sacco A, Rimatori V. Occupational exposure to inhalation anesthetics. Arch Sci Lav. 1990;6(1):37-50.

16. Ministry of Health. [Occupational exposure to anesthetic in the operating room. Circular No. 5 DEL 14/03/198] [Internet]. Rome: The Ministry; 1989 [cited 2014 Dec 12]. Available from: http://www.nonsoloaria.com/Leggi\%20 aria/circ\%205\%2014-03-1989.pdf. Italian.

17. Bradford-Hill A. The environment and disease: Association or causation? Proc R Soc Med. 1965;58(5):295-300.

18. Silman AJ, Hochberg MC. Occupational and environmental influences on scleroderma. Rheum Dis Clin North Am. 1996;22:737-49, http://dx.doi.org/10.1016/ S0889-857X(05)70298-2.

19. Chen M, von Mikecz A. Xenobiotic-induced recruitment of autoantigens to nuclear proteasomes suggests a role for altered antigen processing in scleroderma. Ann N Y Acad Sci. 2005;1051:382-9, http://dx.doi.org/10.1196/ annals.1361.080.

20. York MR. Novel insights on the role of the innate immune system in systemic sclerosis. Expert Rev Clin Immunol. 2011;7(4):481-9, http://dx.doi.org/10.1586/eci.11.40.

21. Magnavita N, Sacco A, Marmiroli L. Vascular, pulmonary and neoplastic pathology in a construction worker. Problems of etiological diagnosis. Med Lav. 1990;81(2):130-7.

22. Hakkou J, Rostom S, Bahiri R, Hajjaj-Hassouni N. Paraneoplastic rheumatic syndromes: Report of eight cases and review of literature. Rheumatol Int. 2012;32(6): 1485-9, http://dx.doi.org/10.1007/s00296-011-2252-9.

23. Shah AA, Rosen A. Cancer and systemic sclerosis: Novel insights into pathogenesis and clinical implications. Curr Opin Rheumatol. 2011;23(6):530-5, http://dx.doi. org/10.1097/BOR.0b013e32834a5081.

24. Moinzadeh P, Fonseca C, Hellmich M, Shah AA, Chighizola C, Denton CP, et al. Association of anti-RNA polymerase III autoantibodies and cancer in scleroderma. Arthritis Res Ther. 2014;16(1):R53, http://dx.doi. org/10.1186/ar4486.

\footnotetext{
This work is available in Open Access model and licensed under a Creative Commons Attribution-NonCommercial 3.0 Poland License / Ten utwór jest dostępny w modelu open access na licencji Creative Commons Uznanie autorstwa - Użycie niekomercyjne 3.0 Polska - http://creativecommons.org/ licenses/by-nc/3.0/pl/deed.en.
} 